\title{
Sheikh Hasina Government's India Policy: A Three-level Game?
}

\section{Bhumitra Chakma}

\begin{abstract}
This article seeks to analyze the sources of the Sheikh Hasina government's India-positive foreign policy approach from theoretical and empirical standpoints. Theoretically, it engages three broad schools of thought and their competing claims about state foreign policy behaviour. These claims then are examined in the context of Bangladesh's foreign policy towards India. It is argued here that three levels—individual, unit/national and external environment—need to be engaged together to understand the sources of the Sheikh Hasina government's India policy.
\end{abstract}

\section{Keywords}

Sheikh Hasina, Bangladesh, India, foreign policy, realism

\section{Introduction}

By winning the 29th of December 2008 general elections, an Awami League (AL)-led alliance formed the government and Sheikh Hasina, for the second time, 1 became the prime minister of Bangladesh. Since then, the Sheikh Hasina government has pursued an India-positive foreign policy and the two countries consequently have built a close relationship that was not evident in the past several decades. The relationship is all-encompassing, stretching from closer trade and economic ties to unprecedented security cooperation. Indeed, except for the period from 1971 to 1975, the Bangladesh-India relationship has not improved to the level that has reached in the past five and a half years. From 1975 to 2008, the Bangladesh-India relationship was marked by ups and down in which mistrust and mutual hostility, rather than cooperation, dominated the dynamics of their bilateral relations. The unprecedented improvement in the Bangladesh-India relationship has raised an intriguing question as to what has contributed to the growth of such a friendly relationship between the two countries in recent years.

This article seeks to analyze the sources of the Sheikh Hasina government's 
India-positive foreign policy approach from theoretical and empirical standpoints. Theoretically, it engages three broad schools of thought and their competing claims about state foreign policy behaviour. These claims then are examined in the context of Bangladesh's foreign policy towards India. It is argued here that three levels—individual, unit/national and external environments—need to be engaged together to understand the sources of the Sheikh Hasina government's India policy.

The article is organized into five sections. First, it provides a theoretical discussion on the sources of states' foreign policy behaviour and the debate surrounding it. In the second section, the article presents an overview of the historical evolution of Dhaka's India policy and the changing patterns of Bangladesh-India relations from 1971 to 2008. This is significant for understanding the extent of changes that has occurred in Dhaka's approach towards India in the past five and a half years. The third section explores the Sheikh Hasina government's India approach and how the relationship has evolved since early 2009. The fourth section analyzes the sources and drivers of the Hasina government's India policy. The final section evaluates the theoretical claims of the three schools in light of the findings of the article.

\section{Theoretical Perspectives: Sources of State Foreign Policy Behaviour}

Scholars of International Relations have vigorously debated the sources of state foreign policy behaviour, but have yet to reach a consensus on the issue. Some scholars argue that domestic factors determine a state's international behaviour; they are known as the Innenpolitik school of thought. A second group-the Aussenpolitik school—holds that the external environment is the key determinant of a state's foreign policy behaviour. These two schools have traditionally dominated the theoretical debate on this issue, although a third group of scholars, who may be considered as the Integrative/Inclusivist school of thought, is discernible in the debate, who argues that while both the traditional perspectives are right in highlighting internal and external variables, they are wrong in prioritizing one over the other. A synthesis of both sets of variables as well as an inclusion of individual/psychological level variables, these scholars argue, are required for a complete understanding of state foreign policy behaviour. These perspectives are explained below in greater detail.

\section{Innenpolitik School}

Scholars of the Innenpolitik school of thought argue that a state's foreign policy is determined by the forces and pressures of domestic politics. Although opinions vary among the scholars within this school on the relative importance of 
various domestic variables, such as political and economic ideology, national character, partisan politics, socio-economic condition, state institutions, the existence and strength of interest groups, bureaucratic politics, the configurations and preferences of dome stic actors, etc., they all share the common assumption that a country’s foreign policy is primarily driven by internal political factors. The roots of foreign policy of a state, therefore, must be located in the social, economic and political structures of states and their configurations and dynamics (for a general discussion on this perspective, see Fearon, 1998; Rose, 1998; Wittkope \& McCormick, 2008).

The Innenpolitik school has a long historical pedigree. Its roots can be traced as far back as Plato. Over the centuries, many scholars have viewed that domestic political dynamics determine external politics rather than the vice versa and this Innenpolitik view has been the key source of criticism against Realism which, as will be discussed below, privileges external factors over the internal ones in explaining state foreign policy behaviour. Marxists, for example, in critiquing Realism have contended that the causes of international conflict could be found within state socio-political and economic structures (Lenin, 1916). Similarly, Liberals have argued that democratic states pursue peaceful foreign policies and non-democratic states go to war due to the lack of check and balance in their political structure (Brown, 1996; Doyle, 1983). Domestic politics, therefore, must be included in any analysis for a complete account of foreign policy (Katzenstein, 1978). Towards the end of the Cold War and following its end, some scholars within the realist tradition became disillusioned with neo- realism's overemphasis on structural sources of state behaviour and called for bringing unit level analysis back within realist theory (Levy, 1988; Snyder, 1991; Zakaria, 1992). Therefore, domestic factors are significant in any analysis of state foreign policy behaviour.

\section{Aussenpolitik School}

The Aussenpolitik school argues that there is the Primat der Aussenpolitik-'the primacy of foreign policy'-in states' international behaviour.2 Kenneth Waltz, the guru of neo-realism, contends that the structure of the international system determines the behaviour of states (Waltz, 1979). This contention highlights the argument of the Aussenpolitik school of thought on state foreign policy behaviour.

Offensive realism, in particular, argues that systemic pressure is the chief determinant of state behaviour in an anarchic international system. Scholars of this variant of structural realism view the international system as 'Hobbesian' in which security is 'scarce'; hence states, as rational egoists, are forced to enhance their relative power position in the system. The key consequence of such anarchy in the international environment is that it is very likely that inter-state conflict will occur. 
Hence, foreign policy is driven by state motivation to enhance its relative power position in the system for security, and systemic pressures and opportunities are the key determinants of states' international actions. This means, contrary to the position of the Innenpolitik school, differences in internal characteristics of countries are relatively unimportant compared to systemic pressures and, regardless of domestic characteristics, similarly situated states will demonstrate similar external behaviour (Gilpin, 1983; Labs, 1997; Mearsheimer, 1990, 2001).

Defensive realism, compared to offensive realism, has a softer view about anarchy and its impact on state behaviour. Scholars of this brand of structural realism posit that the international system is less 'Hobbesian' and provides incentives for moderate and reasonable behaviour, and that security is not 'scarce', but 'plentiful' (Evera, 1984, 1985; Levy, 1987; Posen, 1984; Posen \& Evera, 1987; Snyder 1984; Walt, 1989, 1990). State behaviour is not motivated primarily by aggressive power maximization, and a state responds only to existing real threats instead of hypothetical ones. Some situations, of course, may lead security seekers to fear each other, but such situations are not common. Therefore, an aggressive foreign policy is unnecessary and counter-productive (Walt, 1987). Put simply, the position of defensive realism is that systemic factors influence some kinds of foreign policy behaviour, but not all; when the security dilemma is at a fever pitch, a state will behave aggressively and its behaviour will be driven by systemic incentives; but in normal circumstances, which are more common in the international environment, systemic incentives will play only a marginal role in the foreign policy behaviour of states.

Following the end of the Cold War, when structural realism was on the back foot, a group of realist scholars began to reformulate realist arguments in light of the changed international environment. They attempted to bridge the arguments of offensive and defensive realism while emphasizing how domestic politics plays a critical role in states' responses to structural conditions and pressures. Branded as neo-classical realism, the scholars of this perspective advanced the argument that a country's foreign policy is driven foremost by its place in the international system measured in terms of relative material power capabilities vis-à-vis the rest of the international system. However, the impact of such capabilities is 'indirect' and 'complex' because systemic forces must be translated through an intervening variable at the unit level (Lobell, Ripsman \& Taliaferro, 2009; Rose, 1998; Schweller, 1996; Zakaria, 1992). As foreign policy choices are made by actual political leaders, it is their perception of the country's relative power that matters most in the making of policy choices, not the relative quantities of physical resources (Rose, 1998, p. 147).

Leaders, of course, are constrained by both international and domestic factors. As leaders may not have complete control over the resources to be used for pursuing 
foreign policy, it is important to look at the strength and structure of institutions relative to their societies. It will indicate how resources are distributed and how much is allocated for foreign policy, which, in turn, will have an impact on policy choices. Despite acknowledging the role of domestic factors, neo-classical realist scholars still privilege external variables by arguing that foreign policy theorizing must begin at the systemic level, that is, by interpreting a state's relative position in the system and analysis of unit level variables comes subsequently (Zakaria, 1992).

The key difference between neo-classical realism and the two strands of structural realism—offensive and defensive—-is that while the latter two realisms assume that states seek security, neo-classical realist scholars by contrast posit that states seek to control and shape the external environment in response to the uncertainties of international anarchy (Zakaria, 1999). International anarchy, neoclassical realists believe, is neither Hobbesian nor benign, rather it is murky and opaque. The key implication of this postulate is that it is difficult to clearly tell whether security is scarce or plentiful, hence states must dwell in twilight and act accordingly.

\section{Integrative/Inclusivist Perspective}

Some analysts criticize the Innenpolitik and Aussenpolitik schools of thought by making the point that they focus either on domestic level variables or systemic factors in explaining the foreign policy behaviour of states.3 Such a partial focus, they contend, does not provide a good account of states' foreign policy behaviour. The relationship between international and domestic politics is a two-way traffic and one cannot be privileged at the expense of the other. Rather, the scholars of this perspective maintain, the challenge is how to integrate variables from both the levels and build a framework that can explain which part of foreign policy is influenced by systemic factors, and which part of it is driven by domestic independent variables.

Robert Putnam argues that it is 'fruitless to debate whether domestic politics really determine international relations, or the reverse'. In his view, the challenge really is to know and theorise 'when' and 'how' external and internal politics are entangled and influence the foreign policy behaviour of states (Putnam, 1988, p. 427). Similarly, Zakaria maintains that 'a good account of a nation’s foreign policy should include systemic, domestic, and other influences, specifying what aspects of the policy can be explained by what factors' (Zakaria, 1992, p. 198). Paul Kennedy provides a sophisticated analysis of integrative perspective contextualising Wilhelmine German's Weltpolitik. He specifies which part of the Wilhelmine foreign policy can be explained by systemic factors, and which parts can be explained by domestic structures and Kaiser Wilhelm's personality 
(Kennedy, 1982). Therefore, three levels—systemic, national and individual/personal— need to be taken into account in a sophisticated and complete analysis of a state's international behaviour.

How do the claims of the aforesaid theoretical perspectives account for explaining the Sheikh Hasina government's foreign policy toward India? This article seeks to analyze the Sheikh Hasina government's foreign policy approach towards India in light of the theoretical perspectives presented above. It also draws insights from the analysis about the validity of the theoretical claims.

\section{Bangladesh's India Policy and Bangladesh-India Relations, 1971-2008}

India, as a close and overarching neighbour with far larger capabilities, has been a key factor in Bangladesh's foreign policy ever since the country gained independence in 1971 (Ahmed, 1984; Chauhan, 2012; Hassan, 1989). Many analysts view Bangladesh as an 'India locked' state as the country is surrounded by India on three sides (except $271 \mathrm{~km}$ of land border out of $4142 \mathrm{~km}$ with Myanmar) and the southern sea outlet — the Bay of Bengal—is dominated by the Indian navy (Iftekharuzzaman, 1989, p. 18). Given such a geopolitical location, it is only natural that India historically has figured prominently in the foreign policy of Bangladesh.

Since 1971, Bangladesh-India relations have experienced ups and downs, but the 'India factor', as a positive force or a negative one, has remained constant and continued to affect Bangladesh’s foreign policy behaviour. Indeed, Dhaka’s foreign policy in the past four decades can be seen in a binary fashion: 'pro-India' or 'anti-India'. Such a distinction may seem arbitrary, but it helps to understand the extent of India's influence in Bangladesh's foreign policy. The general trend has been that when an AL government was in power in Bangladesh, it adopted an India-positive foreign policy, while non-AL governments generally maintained an attitude of mistrust towards New Delhi and pursued counterbalancing strategy vis-à-vis India.

The first post-independence government of Bangladesh led by the AL pursued a clear pro-India foreign policy, and during its short tenure from 1971 to 1975, Dhaka and New Delhi developed a very close, cooperative relationship, which is generally dubbed as a period of 'honeymoon' (Rashid, 2010, p. 89). The key reason for adopting such an India-positive foreign policy orientation by the AL government was India’s contribution to Bangladesh’s independence. During the war of independence, India not only provided diplomatic and moral support, it also hosted more than 10 million Bengali refugees for months and, more significantly, intervened militarily and played an instrumental role in the defeat of the Pakistan army in East Pakistan and the birth of independent 
Bangladesh (on the 1971 war, see Jackson, 1975; Sisson \& Rose, 1990). New

Delhi accorded recognition to Bangladesh as an independent state on 6 December 1971, well before the war ended. Hence, it was not surprising that Dhaka pursued an India-positive foreign policy and that the two countries developed a close relationship in the aftermath of the war. Notwithstanding the building of such a friendly relationship, 'seeds of discord' on some issues, however, developed in the later years of the AL tenure (on this, see Hossain, 1984; Hussain, 1989), which came into the open once the AL government was toppled by a bloody military coup in August 1975.

The Bangladesh-India relationship overnight plummeted to a low and became hostile once the AL government was toppled and a military regime, led by General Ziaur Rahman (Zia), took over. Mistrust and mutual hostility were the dominant norms in Bangladesh-India relations during the tenure of the Zia military regime (1975-1981). The military coup was justified on the grounds that the AL government was selling out the country's interests to India and Dhaka had become subservient to New Delhi. The coup and the allegations enraged India. Many of the AL government's initiatives, such as, the creation of a para-military force called Rakkhi Bahini, were perceived by the Bangladesh army as India’s blueprint to keep the armed forces divided and weak in order to perpetuate its influence on Bangladesh.4 It intensified New Delhi's hostility toward the new regime. Additionally, New Delhi became worried about the security implications of a hostile regime in Bangladesh. These developments led to a sharp deterioration of Bangladesh-India relationship during the time of Zia's military rule. New Delhi further hardened its position on Dhaka when Zia began to build a domestic support base by emphasizing a religious identity for the state, which essentially had an anti-India connotation.5

As Bangladesh-India relations became hostile, the Zia regime adopted a counterbalancing strategy by fostering closer ties with China, Pakistan and Muslim countries in order to ease New Delhi's pressure on Dhaka.6 Dhaka's action raised security concerns in New Delhi and went against India's long-held regional security strategy.7 The gap in the security perceptions and strategies of the two countries gradually widened in the ensuing years as both began to pursue mutually destabilising policies. For example, India began to assist Shanti Bahini guerrillas in the Chittagong Hill Tracts who were fighting for regional autonomy, while Bangladesh began to collaborate with China and Pakistan to transfer arms to insurgents in northeast India.8 Consequently, an 'insecurity spiral' set in motion between India and Bangladesh, which deepened their mutual mistrust and hostility. Against such a background, New Delhi hardened its position on various bilateral issues, particularly on the sharing of common river waters that left a devastating environmental impact on Bangladesh. It was clear that the relationship 
was destined to become hostile in the years to come.

The tenure of the first military regime came to an abrupt end in 1981 when General Ziaur Rahman was assassinated in a military coup. It took place in a regional city, Chittagong, which prevented the coup plotters to capture state power. In the presidential election that followed, the Bangladesh Nationalist Party (BNP)9 candidate, Abdus Sattar, was elected and formed the next government. The Sattar government's tenure was short-lived as the army chief, General H.M. Ershad, forced the elected president to cede power to him in March 1982. The second military regime survived in power for eight years until it was forced out of office through a mass movement in December 1990. During the period of the second military regime, Dhaka more or less followed a similar approach towards India as that of its predecessor, the Zia regime. It cultivated the Islamic identity of the Bangladesh polity in a more vigorous way and built closer ties with China, Pakistan and the Islamic states. There was continuity in the country’s India policy; consequently Bangladesh-India relations remained as hostile as in the first military regime.

After 16 years of military rule, Bangladesh began a new democratic journey in the early 1990s. Although a democratic government was installed in Dhaka in 1991, Bangladesh-India relations during the tenure of the first post-military government still remained basically frozen. The key reason for this was that the ruling BNP was created by the first military ruler General Zia and had an inherent anti-India orientation in its foreign policy. New Delhi, on its part, did not demonstrate any goodwill towards the new government or interest in improving the bilateral relations of the two countries. Mistrust and mutual suspicion continued as before; hence little change occurred in Bangladesh-India relations during the tenure of the BNP regime from 1991to 1996.

The relationship turned to the better when the AL returned to power by winning the 1996 general elections. Although far short of the 1970s level of friendship, Bangladesh-India relations improved considerably during the tenure of the Sheikh Hasina-led AL government (1996-2001) as both countries undertook a series of positive steps in order to rebuild the bilateral relationship. For examples, the two countries worked cooperatively to resolve the longstanding dispute over the sharing of the Ganga river water (Hossain, 1998). Although the bilateral relationship of the two countries considerably improved, there were limits to this improvement due to two reasons. First, the AL had a narrow majority in the parliament, which meant that the government had little room to manoeuvre against strong opposition from several political parties, such as the BNP and the Jamat-eIslami. Second, following the installation of a Bharatiya Janata Party (BJP) government in India in 1998, the steady improvement of Bangladesh-India relations was halted. A key reason for this was that the BJP government prioritized the issue 
of illegal immigrants from Bangladesh to northeast India in its approach towards building a better relationship with Dhaka (Wright, 2007).

Relations between the two countries began to deteriorate again when the BNP returned to power by winning the 2001 general elections. The policies of the two countries once again hardened as they developed mutual suspicion in which New Delhi suspected that Bangladesh had a hand in the insurgencies of northeast India10 and Dhaka perceived that India was trying to destabilize Bangladesh. Hence, the old pattern of mutual suspicion and hostility returned in BangladeshIndia relations during the tenure of BNP regime.

Political deadlock and violence in the wake of the 2006 general elections led to the imposition of indirect military rule in Bangladesh in early 2007. The military rule continued until international and domestic pressure forced the military regime to hold general election on 29 December 2008. Although there was some security cooperation during the period of indirect military rule,11 Bangladesh-India relations did not make significant improvement in 2007-2008.

To sum up, Bangladesh pursued a strong India-positive foreign policy during the time of the first post-independence government (1971-1975); consequently the two countries developed a close relationship. After that, barring the tenure of the AL government from 1996 to 2001, mistrust and suspicion were the hallmarks of Bangladesh-India relations from the mid-1970s to the end of 2008.

Dhaka perceived that India posed the greatest security threat to the country's survival as a sovereign state. Contrarily, New Delhi viewed Bangladesh’s cultivation of closer ties with China and Pakistan as inimical to its security interests. Owing to such perceptions, they pursued mutually destabilising policies and consequently developed hostile relationship. This hostile pattern of bilateral relationship changed once the AL returned to power in January 2009 with an overwhelming parliamentary majority.

\section{Sheikh Hasina's India Policy and Bangladesh-India}

\section{Relations: 2009-2014}

Under the garb of a caretaker government, the Bangladesh military indirectly ruled Bangladesh for two years in 2007-2008. As outside and inside pressure grew to return to the democratic path, the military eventually relented and allowed general elections to be held on 29 December 2008 in which a 14-party grand alliance led by the AL gained a landslide victory. The AL-led alliance is still in power as it won the next general elections which were held on 5 January 2014.

Following the formation of the government in January 2009, Prime Minister Sheikh Hasina reassessed Bangladesh's foreign policy, in particular the country's India policy. During the previous tenure from 1996 to 2001, the AL government 
was constrained by the lack of a solid majority in the parliament, but this time there was no such constraint to review the country's foreign policy as the government had an overwhelming majority in the National Assembly. Reversing the preceding government's policy toward India, the Sheikh Hasina government adopted a positive approach toward the big neighbour. Theoretically, there were alternative choices for the government when deciding upon the country's India policy. For example, it could have continued with the counter-balancing policy of its predecessor by maintaining closer ties with China and Pakistan or it could have opted for a 'neutral' or 'balanced' approach, engaging India, China and Pakistan/ Islamic countries simultaneously on an equal footing. The Hasina government clearly chose to draw closer to India and adopted various initiatives to improve Bangladesh's relationship with India.

New Delhi responded positively to Dhaka's initiatives and undertook a series of constructive steps in order to build a cooperative relationship with its eastern neighbour. Exactly a year after she assumed office, Prime Minister Sheikh Hasina went to New Delhi in January 2010 to meet her Indian counterpart, Manmohan Singh. During that visit, the two prime ministers approved a forward-looking, transformative agenda in order to build what they called an 'irreversible' cooperative relationship between the two neighbours (Kumar, 2010). In September 2011, Indian Prime Minister Manmohan Singh paid a return visit to Dhaka to carry forward the transformative agenda which was initiated in 2010.

Notwithstanding the fact that some issues still remain unresolved between the two countries, the relationship indeed has massively transformed since 2009. The remainder of this sub-section provides a brief survey of several important issues in Bangladesh-India relations in politico-security as well as in economic realms and how Dhaka and New Delhi have attempted to resolve them in recent years. It will highlight two important points: (a) the nature of Dhaka's changed India approach and how, despite domestic pressure, the Hasina government has remained committed to fostering better ties with India; and $(b)$ how the Bangladesh-India relationship has evolved and transformed since early 2009.

\section{Politico-security Issues}

\section{Security/Terrorism}

Security cooperation has been a key feature of Bangladesh-India relations since 2009. As discussed in the preceding section, before 2009 the relationship could be defined primarily in terms of mistrust and mutual suspicion and each considered the other as a source of insecurity. After assuming office, the Sheikh Hasina government took several steps to address India’s security concerns, in particular relating to terrorism and insurgency in northeast India. The then foreign minister of the Hasina government, Dipu Moni, assured Indians that Dhaka would not allow Bangladesh territory to be used by terrorists and insurgents (Daily News and 
Analysis, 2009). The Hasina government took action against Harkatul Jihad al Islam (HuJI) and Jamaat ul-Mujahideen Bangladesh (JMB) in due course, and handed over two Laskar-e-Toiba (LeT) members of Indian origin who had been operating from Bangladesh (The Daily Star, 2009). The cooperation of Bangladesh greatly helped New Delhi to tackle the challenges of terrorism within India. Similarly, Dhaka extended cooperation to the Indian authorities to control the challenges of insurgency in the northeast region. In November 2009, law enforcement agencies of Bangladesh captured the United Liberation Front of Assam (ULFA) foreign secretary Sashadhar Choudhury and finance secretary Chitraban Hazarika and handed them over to the Indian security forces. Later, Dhaka also captured and handed over Arabinda Rajkhowa, the ULFA chairman, and his bodyguard, Palash Phukan, as well as the Deputy Commander-in-Chief of ULFA, Hitesh Kalita, to Assam Police (Deccan Chronicle, 2009). Dhaka’s assistance made significant contribution to India's effort to bring the insurgency problem in its northeast region under control.

New Delhi also extended its cooperation to Dhaka on security and intelligence matters. In January 2012, Bangladesh intelligence agencies unearthed a coup plot by some jihadi-leaning military officers against the government. The tip-off, it was subsequently known, came from the Indian intelligence agencies (The Telegraph, 2012). It meant that the security agencies of the two countries were sharing intelligence.

The two countries also took steps to formalize their security cooperation.

During Sheikh Hasina’s visit to New Delhi in January 2010, three agreements were signed on security cooperation. They were: (a) Agreement on Mutual Legal Assistance on Criminal Matters; (b) Agreement on Transfer of Sentenced Persons; and (c) Agreement on Collaboration on Combating International Terrorism, Organised Crime, and Illicit Drug Trafficking. The two countries also initiated discussions on an extradition treaty following Sheikh Hasina's 2010 Delhi visit. An extradition treaty was signed in January 2013 and became operational in October of that year.

Security and intelligence cooperation has been a defining feature of Bangladesh-India bilateral relationship since 2009 which highlights that mistrust and mutual suspicion between the two countries has significantly reduced. It marks a clear departure from previous government's India policy and manifests the Sheikh Hasina government's adoption of a positive approach towards India.

\section{Water Sharing}

The sharing of waters of the common rivers is immensely significant for Bangladesh because it is the lower riparian of almost all 54 rivers that flow through the two countries.12 As India increases the use of water for industrial use and domestic use and withdraws more and more water upstream, this rings alarm 
bells in Bangladesh as it faces adverse environmental, economic and sociopolitical consequences (Gaan, 1998; Islam, 1991).

Although Dhaka and New Delhi resolved the dispute over the sharing of the Ganges water by signing an agreement in 1996, a major issue in their relationship, the dispute over the sharing of waters of other rivers are yet to be resolved. One such river is the Teesta, for which talks between the two countries began in the 1980s. After decades of negotiations, a solution to the sharing of this river water has yet to be found. New Delhi pledged to find an expeditious solution to this problem during Sheikh Hasina’s New Delhi visit in January 2010. After months of painstaking negotiations, an agreement was finalized in the wake of Indian prime minister Manmohan Singh’s visit to Dhaka in September 2011 when the agreement was scheduled to get official stamp. Notwithstanding such an arrangement, the agreement could not be signed due to West Bengal chief minister Mamata Banerjee's last-minute opposition to the deal (The Times of India, 2011). New Delhi pledged to expedite the process of signing the Teesta water sharing agreement in the visit's aftermath, but thus far a final solution to the problem has yet to be found. The failure to sign the Teesta agreement has increased domestic pressure on the Hasina government, in particular from the right-wing political parties. Despite this setback, the positive trend in the bilateral relationship of the two countries has not derailed.

There is also significant resentment in Bangladesh over India's plan for integrated water development which will divert water from India's eastern region to the west and south. Additionally, India's plan to construct a dam at Tipaimukh on the river Barak, which is a tributary of a major river - the Meghna, has raised concern in Bangladesh. The fear in Bangladesh is that it will adversely affect the country in numerous ways. The Hasina government has expressed Bangladesh's concern to New Delhi and raised the issue when Manmohan Singh visited Dhaka in September 2011. Singh assured Hasina that India would not do anything that might harm Bangladesh (Prothom Alo, 2011a).

In the past five years India has strived to accommodate Bangladesh's water interest more than any other time in the past. Notwithstanding the persistence of disputes over the sharing of common river waters, which is natural given the geographic character of the region, both Bangladesh and India have worked to improve bilateral relationship in recent years.

\section{Land and Maritime Boundaries and Enclave Issues}

Originating in the 1947 partition of the subcontinent in the wake of the British colonial withdrawal, the land boundary and enclave issues between Pakistan/ Bangladesh and India still remain unresolved. These issues have complicated the 
relationship between Bangladesh and India ever since the former gained independence in 1971. In 1974, during the 'honeymoon' period of the Bangladesh-India relationship, the two countries signed a comprehensive agreement (the IndiraMujib Land Boundary Agreement) to settle the land boundary dispute once and for all. Although Bangladesh immediately ratified the agreement, New Delhi failed to follow suit. Since then, the land boundary issues have evaded a settlement. After leaving to the backburner for decades, the land boundary and enclave issues have been taken up for serious discussion following the installation of the Hasina government in 2009. During Hasina’s visit to New Delhi in January 2010, the two prime ministers agreed to settle the boundary issues in light of the 1974 Indira-Mujib Land Boundary Agreement and formed a Joint Land Boundary Working Group to expedite the process of finding a settlement to those longstanding issues. They also agreed to resolve the dispute over the maritime boundary in an amicable manner.

During Mammohan Singh’s visit to Bangladesh in September 2011, a protocol to the 1974 Land Boundary Agreement was signed 'to address all outstanding land boundary issues and provide a final settlement to the India-Bangladesh boundary' (The Daily Star, 2011a). It noted the outstanding issues as follows: (a) un-demarcated land boundaries in three sectors, namely, Daikhata-56 (West Bengal), Muhuri River-Belonia (Tripura) and Dumabari (Assam); (b) enclaves; and $(c)$ adverse possessions. Besides, the exchange of adversely possessed lands along the Bangladesh-India border in Tripura, Assam, Meghalaya and West Bengal and 162 enclaves-111 Indian enclaves inside Bangladesh and 51 Bangladeshi enclaves inside India-were finalized when the two prime ministers met in Dhaka. Notwithstanding the Manmohan Singh government's efforts, the Indian parliament has not ratified the deal yet. Until it does so, the boundary agreement will not become operational. In the meantime, a new government in New Delhi led by the BJP has been installed following general elections in May 2014. The new government has yet to indicate its stance on the boundary issue, although the new minister for external affairs, Sushma Swaraj, has paid a visit to Dhaka in June 2014 during which she said that the new government would work towards resolving unresolved issues.

During Manmohan Singh’s 2011 visit to Bangladesh, India also agreed to keep the Tinbigha corridor, which connects Dahagram and Angorporta enclaves with mainland Bangladesh, open for 24 hours, thereby removing a longstanding irritant in Bangladesh-India relations. Sheikh Hasina inaugurated the opening of the corridor round-the-clock in October 2011 (Prothom Alo, 2011b). However, it should be noted that a permanent solution to the enclave issues has yet to be found. The demarcation of the maritime boundary had been a long-standing issue 
between the two countries before it was settled peacefully through an international arbitration in July 2014. Intermittent efforts were made in 1974, 1980 and 2008 for a settlement of the dispute, but bilateral negotiations failed to yield a resolution of the issue (A.K. Gupta, 2008). In 2009, Dhaka went to the Hague-based International Court of Arbitration for a permanent resolution of the maritime boundary dispute between Bangladesh and India (also between Bangladesh and Myanmar). The Court gave its verdict on 7 July 2014 in which it awarded 19,467 sq. km, four-fifths of the total area of 25,602 sq. km disputed maritime area, to Bangladesh. New Delhi has accepted the verdict of the Arbitration Court (Bhattacharjee, 2014).

\section{Economic Issues}

\section{Trade and Investment}

Bangladesh and India have made significant progress on trade and economic matters in the past five years. Historically, trade between Bangladesh and India has favoured the latter and the trade imbalance still remains high: over US\$4 billion in 2010-2011 against Bangladesh.13 Indian leaders have indicated that New Delhi would strive to reduce the imbalance and India has already taken steps in that regard. For example, New Delhi has removed 47 Bangladeshi products from the negative list of imports in order to allow duty-free access of those products in the Indian market (The Telegraph, 2010). Consequently, exports from Bangladesh to India are expected to grow in the coming years. New Delhi also offered a US $\$ 1$ billion line of credit to Bangladesh for 21 projects during the visit of Sheikh Hasina to India in January 2010. It is noteworthy that thus far, this remains the largest offer of such a line of credit by India to a single country.

India also agreed to provide power-starved Bangladesh $250 \mathrm{MW}$ of electricity from its grid, for which the two countries concluded a Memorandum of Understanding (MoU) during Sheikh Hasina's visit to New Delhi in January 2010. Eventually, a formal agreement was signed in March 2012 under which Bangladesh would receive 250 megawatts of electricity from the NTPC Ltd and could buy another 250 MW through competitive bidding (Dawn, 2012).

Additionally, India has offered its assistance to build a 1320 MW electricity production plant in Khulna as a joint venture. Given Bangladesh's severe power shortage, India's assistance could play a vital role in meeting domestic power demand and propelling economic growth. In her first foreign trip to Dhaka in June 2014, barely a month after assumption of office, the BJP government's External Affairs minister Sushma Swaraj has offered an additional 100 MW of electricity from the Palatana Plant in Tripura.

\section{Transit}

New Delhi has long demanded transit facilities from Dhaka to better connect its remote, impoverished northeast region with the mainland. Bangladesh refused to 
accede to this demand arguing that doing so would create security risks and infringe the country’s sovereignty. In fact, Dhaka’s refusal was not so much about security or sovereignty as it was about the poor state of the relationship between the two countries for decades.

A policy shift on the transit issue occurred when the Hasina government revised Bangladesh's India policy and as relations between the two countries began to improve. Sheikh Hasina informed Indian authorities during her visit to New Delhi in 2010 that Bangladesh, in principle, had decided to allow India (and also Nepal and Bhutan) to use the Bangladeshi sea ports of Chittagong and Mongla and the inland water port of Ashuganj (Ejaj, 2010). After more than a year of negotiations, an agreement was made ready for signatures during the Indian prime minister's visit to Dhaka in September 2011, but finally it could not be signed because of New Delhi's inability to sign the Teesta treaty (The Daily Star, 2011b). Dhaka is willing to sign a transit treaty if New Delhi can deliver a treaty on the Teesta.

The above discussion on key issues between Bangladesh and India highlights that both Dhaka and New Delhi have altered their policies radically and have sincerely strived to build a new relationship in the past five years. Notwithstanding considerable domestic opposition in Bangladesh to her government's India policy, Sheikh Hasina has remained persistent with her India policy approach. In the meantime, a new government has taken over power in New Delhi, but it seems that both Dhaka and New Delhi are willing to carry forward the positive trend in the bilateral relationship between the two countries.

\section{Explaining Sheikh Hasina Government's India Policy Approach}

As is evident, the Hasina government, after assuming power in January 2009, adopted a new policy approach towards India, departing from the policy of its predecessor non-AL governments. Consequently, the relationship between the two countries has improved markedly. There were, as noted above, at least three options before the Hasina government when deciding upon its foreign policy orientation: (a) pursue an India-positive policy in order to get closer to the big neighbour; ${ }_{14}$ (b) maintain a counterbalancing strategy, which was the policy of previous non-AL governments by cultivating closer ties with China, Pakistan and Muslim states; and (c) adopt a balanced/non-aligned approach by not getting too close to any of the powers and maintaining equidistance.15 The Hasina government chose the first option. The intriguing question is, why? There is no easy, straightforward answer to the above question because it involves variables that derive from at least three different sources/levels: personal, national and regional/international. Those variables in concert explain, as is discussed below, the Hasina government’s policy approach towards India. 


\section{Individual/Personality Factor}

Prime Minister Sheikh Hasina is the dominant figure within her party, the AL, as well as within the government. Owing to a variety of factors, which are discussed below, she is personally inclined to pursue an India-positive foreign policy and build a closer relationship with that country. To understand the AL government's India policy, one needs to look at the personality of Sheikh Hasina.16 Indeed, to properly appreciate the role of Sheikh Hasina in her government's policy making structure, it is necessary to look at the political culture of Bangladesh, particularly the aspect that relates to the critical importance of certain personalities in Bangladesh politics. Since independence in 1971, Bangladesh politics arguably has evolved in a manner in which personalities, rather than institutions, have been more important. Political parties have seldom practiced a democratic process in choosing the party leaders or office bearers. Bangladesh political parties are personality- centric and revolve around the party leader. Hence, when a party comes to power, the central figure of that party dominates the government and its decision-making.

A quick look at the major political parties of the country makes the point clear. The AL, for example, was dominated by the personality of Sheikh Mujibar Rahmam in the 1970s (Franda, 1982) and since the early 1980s, the party has been dominated by the personality of Sheikh Hasina. Similarly, the BNP was dominated by General Ziaur Rahman in the second half of the 1970s (Jahan, 1980) and by his widow, Khaleda Zia, since the early 1980s. Given the context of Bangladesh political culture, it is therefore arguable that Sheikh Hasina's personality is decisive in government decision-making and the adoption of an India-positive foreign policy approach is attributable to her personality.

Sheikh Hasina's positive perception about India is principally formed through her personal experiences and ideological stance. Her party, the AL, led the war of independence in which India played a critical role; this must have left a feeling of gratefulness in her towards India. Moreover, her father Mujibar Rahman, as the head of the first post-independence government, developed a very close relationship with New Delhi. She inherited the mantle of the Bangladesh-India relationship of the 1970 s.

Following the assassination of her father and most of the family members in the 1975 military coup, Sheikh Hasina was in exile in New Delhi and received the hospitality of the Indian government until she returned to Bangladesh in May 1981. A causal link between her exile in Delhi and her government's India policy cannot be directly established; however, it is logical to assume that she must have felt a debt of gratitude to the Indians for the generosity she received during those difficult years of her life. Moreover, during her exile in Delhi, she developed personal friendship with many Indian leaders. Here again, although a 
causal link between this and her government's India-positive foreign policy cannot be established, it would nonetheless be fair to make a general point that such personal factors are important in diplomacy and foreign policy choices in general.

Additionally, Sheikh Hasina's ideological stance - a commitment to secularismis arguably a significant factor in understanding her world view and foreign policy approach. As India is a secular state, hence Hasina’s ideological orientation and the experience of 1971 make it natural for her to favour an India-positive foreign policy rather than choosing Pakistan or China as a counter-weight to India.

The key point to take home from the above discussion is that the personality factor is important in Bangladesh politics and the government decision-making structure, and that Sheikh Hasina played a decisive role in choosing an Indiapositive foreign policy orientation of the AL government. She continues to play a dominant role in the continuation of the policy option that was adopted at the beginning of her government in 2009.

Notwithstanding the critical importance of the personality factor, it is imprudent to neglect the significance of the role of other factors which primarily derive from the national level variables and the external environment. To say that Sheikh Hasina plays a central role in foreign policy decision-making does not mean that she has complete freedom or control over foreign policy decision-making and/or its practice. She is constrained by domestic political dynamics and configuration of forces within the state as well as the external forces. After all, foreign policy is not made in a vacuum. Internal dynamics and external environment constantly put limits and constraints on decision makers. For example, the major opposition political party — the BNP—was created by the first military ruler General Ziaur Rahman on an anti-India platform and in building the party he significantly used Islam as a tool. Hence, the BNP generally pursues a foreign policy which is not India-positive. Now, the BNP has an alliance with Jamaat-i-Islami which is inherently anti-Indian. As noted earlier, they receive support from a section of the Bangladesh polity which prefers an Islamic identity for the Bangladesh state. Consequently, it constrains Shekih Hasina’s freedom to pursue India-positive foreign policy in view of the fact that a section of Bangladesh population opposes building closer ties with India. The implication of this is that even though her personality was instrumental in choosing an India-positive foreign policy orientation, its success (or lack of it) is determined by impersonal forces beyond her control. Therefore, the Hasina government's India policy needs to be viewed as a product of competing forces and pressures. Further, impersonal factors that influence her perception put constraints and limits on her government's actions. The key point here is that she might have made the choice to adopt an India-positive 
foreign policy orientation, but her policy practice is constantly affected by factors beyond her control and her foreign policy does not always function in a way that she always wishes.

\section{Unit/National Level Factors}

Domestic-level variables are at play in the Hasina government's India policy. Indeed, variables of this level work in a contradictory fashion. Some of them facilitate her government's positive policy approach towards India, while others impose constraints and limits. Most significantly, the latter set of variables negates Sheikh Hasina's freedom of action on India policy, which deserves careful consideration.

The AL's ideological orientation was a strong facilitating factor in the Hasina government's decision to adopt an India-positive foreign policy. As noted above, the Bangladesh polity is more or less equally divided into two broad sections in terms of national identity. A first group emphasises the Islamic character of the polity, while the second group prefers secularism as the state ideology. The AL represents the views of the latter section of the polity, which draws the party closer to India. The historical pattern of Bangladesh-India relationship reflects that when the Indian National Congress in India and AL in Bangladesh are in power, the relationship between Dhaka and New Delhi tends to be closer. When the AL came to power in 2009, a Congress-led United Progress Alliance was in government in New Delhi. Hence, an argument can be made that ideological affinity of the two political parties brought Dhaka and New Delhi closer. Of course, it is also noteworthy that in general an AL government tends to develop better relations with India than any other party in Bangladesh.

On the other hand, those who emphasize Islamic identity tend to position themselves on the other side of the scale; that is, if the secularists see India as a ' natural' friend, the Islamists see that country primarily through the opposite prism. As noted earlier, the revival of Islamic identity in Bangladesh politics after 1975 had an anti-India tone. Several major political parties, including the BNP, represent this section of the Bangladesh polity. The division within the Bangladesh polity on identity makes India an important factor in the political dynamics of the country, particularly in election politics (Pattanaik, 2005). The implication of this factor for the AL government's India policy is that it constrains Sheikh Hasina's and her government's freedom of action in pursuing an India-positive foreign policy. The scope and continuity of the Hasina government's India policy is, therefore, greatly affected by the country's domestic politics.

\section{Regional/International Factors}

Rapid transformation in the regional/international geo-economic and geo- political 
structure after the end of the Cold War has had a profound impact on the Hasina government's adoption and pursuit of India-positive foreign policy. For one thing, the transition of the South Asian region and even beyond has been a key factor that informed the perception of the Hasina government's policy elite, including Prime Minister Sheikh Hasina. For another, a pragmatic appreciation of the changes at the regional and international levels has made it imperative to adopt foreign policy that would serve its political and economic security.

Bangladesh's geopolitical location makes it India-dependent in many respects. The country is not only surrounded by India on three sides, it is also the lower riparian of almost all 54 common rivers. The key implication of this factor is that it is daunting for Bangladesh to make progress by pursuing an anti-India foreign policy and maintaining a hostile relationship with that country. Hence, prudence suggests that Bangladesh must work with, and not against, India to promote its interests and progress. This perception is common among the Hasina government's policy elite. For example, Gowher Rizvi, Sheikh Hasina’s international affairs advisor, maintains that in Bangladesh there is 'a realisation that India is our biggest and closest neighbour, and the earlier policy of hostility is futile in a rapidly globalising society’ (The Hindu, 2011).

The view that Bangladesh must work with India for its own interest became even more important in the context of the latter's gradual rise as a global power.17 Since India adopted economic reform policies in 1991, its economy has grown at a rapid pace and is now poised to become the world's third largest economy in the coming decades. Further, the growing strategic partnership between India and the United States symbolized in particular by the conclusion of a landmark nuclear cooperation agreement in 2008, and by the American commitment to help India's rise as a global power, have enhanced India’s rising power image in Bangladesh. It has lifted the incentive for Bangladesh to work with India.

Simultaneously, the demonstration effect of economic growth of China and India and their model of cooperation have left a positive impact on Bangladeshi policy elites. Despite longstanding border disputes and strategic rivalry, New Delhi and Beijing have found reasons for cooperation, in particular in the areas of trade and investment. If China and India can cooperate on that basis, there is no reason why other states will not be able to work together in a similar fashion. Economic growth now forms an important element of the Hasina government's foreign policy. There has been an emphasis on regional connectivity project in Bangladesh's diplomacy in the past five years which aims to connect regional states, including China and India, to propel economic growth (Zaman, 2014). Dhaka sees itself at the crossroads of South, Central and Southeast Asia and as a bridge between the three regions. The country's interest in the participation of the 
Kunming initiative or BCMI (Bangladesh, China, Myanmar, India) is a reflection of this perception; its objective is to tap economic opportunities in the country's surrounding areas. A friendly relationship with India is therefore significant for Bangladesh.

The above discussion highlights that a variety of factors influenced the Hasina government's decision to adopt and pursue an India-positive foreign policy approach. First of all, it is important to factor Prime Minister Sheikh Hasina's personality in understanding the AL government's foreign policy orientation. Of course her choice was supported by her party’s ideological orientation (a unit level variable).

While the initial decision to opt for a particular foreign policy approach can be explained in terms of Sheikh Hasina's personality, its practice cannot be explained by that factor alone. Sheikh Hasina remains a driving force behind the Indiapositive foreign policy orientation of the AL government, but its dynamics is constantly challenged, and consequently modified, by impersonal factors. Two very important factors in this context are particularly important. One is the ideological stance of a segment of the Bangladesh polity, which emphasizes an 'Islamic identity', as opposed to secularism, and is represented by political parties such as the BNP, Jamaat-e-Islami, etc. These political forces constrain the freedom of action of the AL government in the pursuit of an India-positive foreign policy. Second, New Delhi's policy actions towards Bangladesh are significant for the sustenance of the Hasina government's India-positive foreign policy. Without India's positive reciprocity, it would be difficult for the AL government to persist with the Indiapositive foreign policy approach (an external variable). These two factors derive from two different levels, namely, national and external. Here domestic level variables - the configuration of domestic political forces and the ideological division of the Bangladesh polity_and external variables, that is, India's actions towards Bangladesh, act in an interactive fashion and affect the pursuit of Sheikh Hasina government's India policy.

\section{Conclusion: Theoretical Implications}

The Hasina government's India-positive foreign policy does not derive from a single source, it is indeed a product of multiple interactive variables emanating from different sources/levels. These variables can be located at the personal, national/domestic and regional/international levels. It is difficult to prioritize one factor over another in analyzing the AL government's foreign policy pursuits. Instead, they must be analyzed eclectically in order to make sense of the Hasina government's India policy. This observation needs to be viewed in the light of 
the debate, as discussed in the theoretical section, between the Innenpolitik and the Aussenpolitlik schools of thought on state's international behaviour in which each prioritises a set of variable deriving either from domestic or external sources. It means that the conclusion of this paper is a critique of that theoretical debate and takes the position that the three sets of variables are inseparable; indeed, they are complementary and work in concert in an interactive manner. Hence, only an integrated approach that combines variables from three levels provides a complete account of the Hasina government's India policy, in particular, and Bangladesh's foreign policy, in general. Put simply, this article concludes that the alternative theoretical approach beyond the Innenpolitik-Aussenpolitik debate provides the best explanation of state foreign policy behaviour and its sources.

The arguments of the Aussenpolitik school are best represented by the two variants of structural realism—offensive and defensive. But they are unable to explain the India policy of the Hasina government and Bangladesh's foreign policy behaviour. If they are right, particularly the offensive variant, Dhaka would have viewed India as a threat and therefore, would have exhibited balancing behaviour by invoking China or another power as a countervailing power. Indeed, this strategy in Bangladesh foreign policy can be observed, as discussed in this article, in the second half of the 1970s and the 1980s during the tenures of the two military regimes in which they cultivated closer ties with China, Pakistan and Muslim states in general. Yet it is noteworthy that there was an element of domestic politics in their foreign policy behaviour. For example, they pursued such a foreign policy in order to distance themselves from New Delhi which indeed was to gain support from a section of the Bangladesh polity who were (and still are) inherently opposed to India. Counterbalancing India was not the driving factor of the context of the Hasina government's India policy and the AL government's foreign policy in general. Therefore we need to look for explanation of the Hasina governments India policy elsewhere.

The Innenpolitik school of thought alone does not explain the Hasina government's India positive foreign policy either. This school privileges internal dynamics and mainly focuses on domestic factors, which makes it an inadequate framework for understanding Dhaka’s India policy. There is little doubt that domestic dynamics has been immensely important in understanding Sheikh Hasina government's foreign policy. Also as explained above, Sheikh Hasina’s personality factor was a key driver in choosing the foreign policy options. But the external environment, either by providing opportunities or by imposing constraints, also played a significant role in the Hasina government's foreign policy behaviour. For example, sub-regional integration is viewed by the policy elites in 
a positive light because it would be immensely important for the country's economic growth. Only a positive and friendly relationship with India can achieve the goal of sub-regional economic integration. Bangladesh's emphasis on Bay of Bengal Initiative for Multi-Sectoral Technical and Economic Cooperation (BIMSTEC) is a clear example of this approach of the Hasina government. Therefore it is evident that the unit level factors alone cannot provide a complete understanding of the Hasina government's India policy.

As the preceding section has highlighted, identity at the personal and unit level has played an important role in Hasina's India policy. Here the Constructivist approach of International Relations appears to provide an explanatory framework for understanding Dhaka’s policy approach towards India under Sheikh Hasina (an influential work on Constructivism is Wendt, 1992). Although the issue of identity is critical in shaping Sheikh Hasina's foreign policy, it is difficult to ignore other non-identity factors. For example, the identity formation at the unit level is influenced by India's behaviour towards Bangladesh. Hence, it can be posited that despite its significance, it only provides a partial account of Hasina's India policy approach.

Neo-classical realism's arguments come very close to explaining the foreign policy of the Hasina government, as it combines both domestic and external/ systemic factors. However, its claim that foreign policy analysis must begin by explaining a state's relative power position in the international system does not quite fit in the case of the Hasina government's foreign policy, particularly since there was no significant change in the structural position of Bangladesh vis-à-vis India. Furthermore, counterbalancing is clearly not the preferred option of the Sheikh Hasina government's foreign policy towards India. An explanation of Sheikh Hasina's India policy, therefore, needs to begin by looking at her personal preference or domestic political dynamics rather than Bangladesh's relative power position in the international system or its position vis-à-vis India.

The Integrative perspective, particularly Paul Kennedy’s approach, does provide a better framework for understanding the Hasina government's India-positive foreign policy orientation. The Hasina government's foreign policy highlights that variables can be located at three levels_-personal, unit/national and external—and they act in a complementary and interactive manner. For example, the Indian behaviour towards Bangladesh influences domestic public opinion and political dynamics in Bangladesh, which in turn influences Dhaka’s policy approach towards India. Indeed, it is possible to look at different parts and stages of Sheikh Hasina's India policy by employing variables at different levels. For example, the initial decision to foster closer ties with New Delhi was based on Hasina's own personal preference. Subsequently, the practice of that policy was modified by constraints imposed by domestic and regional/international variables. For example, at the 
domestic level, the BNP-led alliance which includes Jamaat-i-Islami is opposed to closer ties with India, at least to the extent that the Hasina government intends to pursue. Therefore, it is arguable that for a complete account of foreign policy one should not privilege a particular source, rather appropriate variables should be identified to explain different parts of a country's foreign policy.

\section{Acknowledgement}

An initial draft of this article was published as an RSIS Working Paper entitled 'Bangladesh-India Relations: Sheikh Hasina's India-Positive Foreign Policy Approach' by the S. Rajaratnam School of International Affairs (RSIS), Nanyang Technological University, Singapore, in November 2012. I received a fellowship from the South Asia Program of RSIS to conduct this research. I am very grateful to the South Asia Program, particularly to its coordinator Professor Rajesh M. Basrur, for facilitating this study. I am also indebted to the two anonymous reviewers of the JASIA for their helpful comments on a draft of this article.

\section{Notes}

1. Sheikh Hasina's first tenure as prime minister was from 1996 to 2001. Following the completion of the five-year term from 2009, general elections were held on 5 January 2014 in which the AL-led alliance gained a landslide victory. This election remains controversial because several major political parties, including the Bangladesh Nationalist Party (BNP), boycotted it.

2. There are two competing arguments in this regard within the Aussenpolitik school. The first is that the patterns of international relations strongly influence domestic arrangements of states. The second is that states conduct their foreign policy as a consequence of international pulls and pushes, and not to advance domestic ends. For a brief but useful discussion on the origins of these two schools of thought, see Zakaria (1992).

Zakaria maintains that, '[O]ver the last decade, scholars of international relations have either ignored the international system or never moved beyond it' (Zakaria, 1992, p. 198). 4. It is noteworthy that the Rakkhi Bahni was dismantled by the Zia military regime immediately after taking over power.

5. Professor Akmal Hussain of Dhaka University discussed this point at length in an interview with this author on 4 February 2012. In his view, the emphasis on Islamic identity was a return to the old Hindu-Muslim divide that existed in the subcontinent's politics since the time of British colonial rule. For a perceptive analysis of the historical process of the Islamization of Bengal, the changing frontiers and its implications for today’s Bangladesh-India relations, see Ghose (2012).

6. Bangladesh perceived India's hostility as a serious threat to its survival as a sovereign entity, which was amplified in the wake of Sikkim's merger with the Indian Union in 1975; hence, the cultivation of closer ties with China and Pakistan was a counterbalancing strategy to ward off the India 'threat'. For a discussion on this point, see Chakma (2009).

7. India adopted the security strategy of the British Raj following independence and 
conceived its security in terms of the subcontinent and the Indian Ocean region. Hence, India perceived Bangladesh’s closer ties with China and Pakistan as inimical to its security interests. For a discussion on the historical origins of this Indian strategy, see Kavic (1967) and Kodikara (1984). For a modern version of India’s regional security doctrine, see B.S. Gupta (1983) and Hagerty (1991).

8. Subir Bhaumik terms such assistance to insurgent groups against each other as 'proxy wars’. See Bhaumik (1996).

9. It is noteworthy that the Bangladesh Nationalist Party was created by the first military ruler, General Ziaur Rahman. Hence, although a civilian government was installed with Abdul Sattar as president, the policies of the military regime continued during the tenure of the short-lived civilian government. It meant that Bangladesh-India relations were not affected by the advent of a civilian government in Dhaka and the basic premise of the relationship remained as before.

10. In a landmark case involving the transfer of weapons to insurgent groups in northeast India, a Bangladesh court handed down death penalty to 14 persons. The incident took place during the tenure of BNP government (The Times of India, 2014).

11. For example, the Bangladesh Rifles reportedly destroyed two Indian militant camps inside Bangladesh territory in the Chittagong Hill Tracts region in late 2007 (The Indian Express, 2007).

12. Bangladesh and India share 54 common rivers; 51 rivers originate in India (or China but flow through Indian territories before entering into Bangladesh) and three rivers originate in Bangladesh but enter into India before entering again to Bangladesh and eventually pump into the Bay of Bengal.

13. In 2008-2009, 2009-2010 and 2010-2011, Bangladesh’s imports from India were US\$2841.58 million, US\$3202.00 million and US\$4586.80 million respectively, and exports to India were US\$276.58 million, US\$305.00 million and US\$512.5 million respectively. See, Ministry of External Affairs, Government of India, 2012. Perhaps in the near term trade imbalance will continue to remain before it comes down in the longer run with further concrete measures.

14. The Hasina government's India-positive policy is not bandwagoning in the classical theoretical sense of the term (on bandwagoning, see Schweller, 1994) because Dhaka has been pursuing such a policy even before India demonstrated its potential as a rising power during the times of previous AL governments. Indeed, an India-positive policy is a pragmatic one given the locational context of the country in which Bangladesh is almost an India-locked state.

15. It is noteworthy that because of its location in which Bangladesh is surrounded by India on three sides, it either has to accept considerable Indian influence or oppose it. Furthermore, since its independence Bangladesh has found itself in the vortex of geopolitical competition between India, on the one hand, and China and Pakistan, on the other. Even the superpowers were involved in this game. Hence, this dichotomy has been apparent in Bangladesh foreign policy ever since it emerged as an independent state in 1971. Hence, neutrality or equidistance is not an easy option for Bangladesh. 16. Analyst Amena Mohsin, a professor of International Relations at the University of Dhaka, strongly holds such a view; interview with the author in Dhaka on 5 February 2012.

17. India's global power status is yet to be certain, but analysts believe that India's rise 
is now inevitable. As an analyst puts it: 'Experts recently stopped asking if India will become a great power and began to wonder what kind of great power it will become' (Lavoy, 2007, p. 114).

\section{References}

Ahmed, E. (ed.). (1984). Foreign policy of Bangladesh: A small state’s imperative. Dhaka: University Press Ltd.

Bhattacharjee, R. (2014). Delimitation of Indo-Bangladesh maritime boundary. IDSA Comment, 19 August. Retrieved from http://www.idsa.in/idsacomments/DelimitationofIndo-Bangladesh_ rbhattacharjee_190814.html

Bhaumik, S. (1996). Insurgent crossfire: North-East India. New Delhi: Lancer Publishers. Brown, M.E. (1996). Debating the democratic peace. Cambridge: The MIT Press.

Chakma, B. (2009). South Asia's realist fascination and the alternatives. Contemporary

Security Policy, 30(3), 395-420.

Chauhan, K.S. (2012). Foreign policy of Bangladesh. New Delhi: Kaveri Books.

Daily News and Analysis. (2009, December 6). Bangladesh vows not to allow terrorists to use its land. Daily News and Analysis.

Dawn. (2012, March 4). Bangladesh to buy 500 MW of electricity from India. Dawn.

Deccan Chronicle. (2009, December 4). ULFA chief handed over to India. Deccan

Chronicle.

Doyle, M. (1983). Kant, liberal legacies, and foreign affairs: Part 1 and Part II. Philosophy and Public Affairs, 12(3 \& 4), 205-235, 323-353.

Ejaj, R. (2010, January 13). Consensus on sea-rail-road use. Prothom Alo.

Evera, S.V. (1984). The cult of the offensive and the origins of the First World War. International Security, 9(1), 58-108.

. (1985). Why cooperation failed in 1914. World Politics, 38(1), 80-118.

Fearon, J. (1998). Domestic politics, foreign policy and theories of international relations.

Annual Review of Political Science, 1(June), 289-313.

Franda, M. (1982). Bangladesh: The first decade. New Delhi: South Asian Publisher.

Gaan, N. (1998). Environmental degradation and conflict: The case of Bangladesh-India.

Dhaka: Parma.

Ghose, P.S. (2012). Changing frontiers: Making deep sense of India-Bangladesh relations.

South Asia Research, 31(3), 195-211.

Gilpin, R. (1983). War and change in world politics. Cambridge: Cambridge University Press.

Gupta, A.K. (2008). Indo-Bangladesh maritime border dispute: Problems and prospects.

IPRS (Institute of Peace and Conflict Studies) Article, No. 2699, 7 October. Retrieved

from http://www.ipcs.org/article/india/indo-bangladesh-maritime-border-dispute-problemsandprospects-2699.html

Gupta, B.S. (1983). The Indian doctrine. India Today, 31 August.

Hagerty, D.T. (1991). India’s regional security doctrine. Asian Survey, 31(4), 351-363.

Hassan, S. (1989). The India factor in the foreign policy of Bangladesh. In Kabir, M.G. \&

Hassan, S. (eds), Issues and challenges facing Bangladesh foreign policy (pp. 44-61).

Dhaka: Bangladesh Society of International Studies.

Hossain, I. (1984). Bangladesh-India relations: Issues and problems. In Ahmed, E. (ed.), 
Foreign policy of Bangladesh: A small state's imperative (pp. 34-51). Dhaka:

University Press Ltd.

. (1998). Bangladesh-India Relations: The Ganges water sharing treaty and beyond. Asian Affairs, 25(3), 131-150.

Hussain, A. (1989). The Bangladesh-India relations 1972-75: Seeds of future discord. In Ahmed, M. \& Kalam, A. (eds), Bangladesh foreign relations: Changes and directions (pp. 9-19). Dhaka: University Press Ltd.

Iftekharuzzaman. (1989). The India doctrine: Relevance for Bangladesh. In Kabir, M.G. \& Hassan, S. (eds), Issues and challenges facing Bangladesh foreign policy (pp. 18-43).

Dhaka: Bangladesh Society of International Studies.

Islam, N. (1991). The Ganges water dispute: Environmental and related impacts on Bangladesh. BIISS Journal (Dhaka), 12(3), 263-292.

Jackson, R. (1975). South Asian crisis: India, Pakistan, and Bangladesh. London: Chatto and Windus.

Jahan, R. (1980). Bangladesh politics: Problems and issues. Dhaka: University Press Ltd. Katzenstein, P.J. (ed.) (1978). Between power and plenty: The foreign economic policies of advanced industrial states. Madison: University of Wisconsin Press.

Kavic, L.J. (1967). India's quest for security: Defence policies, 1947-1965. Los Angeles: University of California Press.

Kennedy, P. (1982). The Kaiser and German Weltpolitik: Reflections on Wilhelm II's place in the making of German foreign policy. In Rohl, J.C.G. \& Sombart, N. (eds), Kaiser Wilhelm II: New interpretations (pp. 143-168). New York: Cambridge University Press.

Kodikara, S. (1984). Strategic factors in interstate relations in South Asia. New Delhi: Heritage Publishers.

Kumar, A. (2010). Shaikh Hasina's visit to India and the future of Indo-Bangladesh relations. Asian Affairs, 41(3), 422-435.

Labs, E.J. (1997). Beyond victory: Offensive realism and the expansion of war aims. Security Studies, 6(4), 1-49.

Lavoy, P.R. (2007). India in 2006: A new emphasis on engagement. Asian Survey, 47(1), 113-124.

Lenin, V.I. (1916, reprint in 1939). Imperialism: The highest stage of capitalism. New York: International Publishers.

Levy, J.S. (1987). Declining power and the preventive motive for war. World Politics, 40(1), 82-107.

(1988). Domestic politics and war. Journal of International History, 18(4), 653-673.

Lobell, S.E., Ripsman, N.M., \& Taliaferro, J.W. (eds). (2009). Neoclassical realism, the state and foreign policy. Cambridge: Cambridge University Press.

Mearsheimer, J. (1990). Back to the future: Instability in Europe after the Cold War. International Security, 15(1), 5-56.

(2001). The tragedy of great power politics. New York: W.W. Norton and Company.

Ministry of External Affairs, Government of India. (2012). India-Bangladesh relations.

Retrieved from http://mea.gov.in/mystart.php?id=50042439 
Pattanaik, S.S. (2005). Internal political dynamics and Bangladesh's foreign policy towards India. Strategic Analysis, 29(3), 395-426.

Posen, B.R. (1984). The source of military doctrine: France, Britain and Germany between two world wars. Ithaca, NY: Cornell University Press.

Posen, B.R., \& Evera, S.V. (1987). Reagan administration defense policy: Departure from containment. In Oye, K.A., Lieber, R.J., \& Rothchild, D. (eds), Eagle resurgent? The Reagan era in American foreign policy (pp. 75-114). Boston: Little Brown.

Prothom Alo. (2011a, September 6). Will not do anything which harms Bangladesh.

Prothom Alo.

(2011b, October 22). New start for Dahagram-Angorpota. Prothom Alo.

Putnam, R.D. (1988). Diplomacy and domestic politics: The logic of two-level games.

International Organization, 42(3), 427-460.

Rashid, H.u. (2010). Bangladesh foreign policy: Realities, priorities and challenges.

Dhaka: Academic Press and Publishers Library.

Rose, R. (1998). Neoclassical realism and theories of foreign policy—A review article.

World Politics, 51(1), 1441172.

Schweller, R.L. (1994). Bandwagoning for profit: Bringing the revisionist state back in. International Security, 19(1), 72-107.

. (1996). Neo-realism's status quo bias—What security dilemma? Security Studies, 5(3), 90-121.

Sisson, R., \& Rose, L.E. (1990). War and session: Pakistan, India, and the creation of Bangladesh. Berkeley: University of California Press.

Snyder, J. (1984). The ideology of the offensive: Military decision making and the disaster of 1914. Ithaca, NY: Cornell University Press.

. (1991). Myths of empire: Domestic politics and international ambition. Ithaca, NY: Cornell University Press.

The Daily Star. (2009, November 24). 2 Laskar men held inside Indian border. The Daily Star.

. (2011a, September 7). Details of the deals. The Daily Star.

. (2011b, September 7). Transit sinks in Teesta waters. The Daily Star.

The Hindu. (2011, September 6). India-Bangladesh ties is a model for South Asia. Interview with Dr Gowher Rizvi. The Hindu.

The Indian Express. (2007, December 6). Bangla destroyed two Indian militant camps on its soil: BSF. The Indian Express.

The Telegraph. (2010, January 12). Wider access to Bangla goods. The Telegraph.

. (Kolkata, 2012, January 21). Delhi 'tip-off' helped foil coup. The Telegraph.

The Times of India. (2011, September 6). Teesta pact with Bangladesh put off after Mamata sulk. The Times of India.

. (2014, January 30). Bangla court sentences ULFA chief Paresh Barua to death.

The Times of India.

Walt, S.M. (1987). The search for a science of strategy: A review essay on makers of modern strategy. International Security, 12(1), 140-166.

Walt, S.M. (1989). The case for finite confrontation. International Security, 14(1), 5-50.

- (1990). The origins of alliances. New Jersey: Cornell University Press.

Waltz, K. (1979). Theory of international politics. Reading, MA: Addison-Wesley. 
Wendt, Alexander. (1992). Anarchy is what states make of it: The social construction of power politics. International Organization, 46(2), 392-425.

Wittkope, W., \& McCormick, J. (eds). (2008). The domestic sources of American foreign policy: Insights and evidences. Lanham, MD: Rowman and Littlefield.

Wright, D. (2007). Bangladesh and the BJP. South Asia: Journal of South Asian Studies, 25(3), 381-393.

Zakaria, F. (1992). Realism and domestic politics: A review essay. International Security, 17(1), 177-198.

. (1999). From wealth to power: The unusual origins of America. Princeton, NJ: Princeton University Press.

Zaman, S.S. (2014, March 17). Dhaka working on BCMI corridor. Dhaka Tribune. 